\title{
10. How Do Australians Search for Jobs?
}

\author{
Xianbi Huang and Mark Western
}

Getting a job is one of the most significant events in people's lives. People's jobs substantially determine their financial circumstances and those of their families, can affect their psychological and physical health and wellbeing and may also influence their economic, social and political attitudes and behaviour. Getting a job is one of the important symbolic markers of becoming an adult and, conversely, not having a job, especially in households where no-one has a full-time job, is a major cause of poverty. In times of economic hardship and financial insecurity, getting and keeping jobs are also more difficult than when the economy is booming.

How people search for jobs has therefore been a vibrant and heated topic in international research since the seminal study of American sociologist Mark Granovetter in the 1970s. Granovetter (1974) conducted personal interviews and mail surveys with 282 professional, technical and managerial workers in a Boston suburb and published his book Getting A Job: A study of contacts and careers, which turned out to be a classic work that has been widely cited and highly influential. Granovetter's book refuted many of the taken-for-granted understandings about how people obtained their jobs. The key findings were the following: using personal contacts was the predominant method of obtaining jobs; job information secured through personal contacts was of higher quality than information obtained by other means; and better jobs with higher pay and prestige and affording greater satisfaction were more likely to be filled via personal contacts. Behind these findings is the crucial recognition that individuals are embedded in social networks and these networks influence how labour markets work. We cannot understand real labour markets without recognising this argument. Over the past three decades substantial research from this perspective about job searches has been stimulated in many capitalist and non-capitalist countries. Extensive research from Europe, North America and Asia has shown that, compared with other job-search methods, social networks play a significant role in accessing diverse social resources for securing jobs in different social contexts (Bian 1997; Bian and Soon 1997; De Graaf and Flap 1988; Lin, Ensel and Vaughn 1981; Yakubovich and Kozina 2000). So far, however, systematic research into this topic is rare in Australia.

In this chapter, we address the question of how Australians search for jobs by drawing on data from the Australian Survey of Social Attitudes (AuSSA) 2007 (Phillips et al. 2008). We first describe the different job-search methods used in Australia and then investigate who uses the different kinds of methods. Next, we explore what kinds of social resources job-seekers access through their social networks and what types 
of social ties or relationships individuals rely upon. We then look at how effectively different job-search methods 'match' individuals to jobs, and finally summarise our main research findings and discuss the implications of our research.

\section{How do people search for jobs?}

Australians, like others, rely on various job-search methods: looking at advertisements in newspapers or the Internet, using employment services, attending job and employer fairs, asking for help from friends or relatives, and so on. Researchers classify these different job-search methods in different ways such as non-personal means versus personal means (Bridges and Villemez 1986), formal channels versus informal channels (Boxman et al. 1991), personal contacts, formal channels and direct application (Lin et al. 1981). In essence, however, these job-search methods fall into three types: hierarchy, market and networks (Bian 2002; Granovetter 1995). Hierarchical methods of job searching refer to job assignments and organised transfers by a state authority or employing organisation. This is/was the most frequently used method in state socialist economies (Bian 1997) but is not confined to them. In Western societies, like Australia, organisational reallocations or transfers are also included under hierarchical methods. Market methods refer to job-search activities in which people individually seek jobs among employers, such as attending job fairs where employers gather to recruit employees, using formal employment services, applying directly to employers, responding to media advertisements, looking for jobs online, and so on. Network methods refer to any search activities in which people draw on personal assistance from others, mobilising social ties and connections to secure employment. We adopt this analytical scheme to examine Australians' job-search methods by using data from the AuSSA 2007.

The AuSSA 2007 asked which job-search method was mainly used in different stages of the process of finding a job. Respondents were asked three questions: 1) 'Of the following methods, which one did you mainly use in looking for your current or last job?'; 2) 'Among the methods you used to look for a job, which one was most helpful to get a job interview?'; and 3) 'On the whole, which one method was most important for getting your current or last job?' The job-search methods listed for their choice include: 'Looked at media advertisements', 'Used university career services', 'Used an employment agency', 'Used the Internet', 'Got help or information from family or relatives', 'Got help or information from friends', 'Got help or information from acquaintances', 'Approached an employer', 'An employer approached me', 'I was reallocated or transferred by the organisation I work for', 'I am self-employed', 'Other', and 'Don't know'. Since our research interest focuses on the effect of jobsearch methods, we do not include the self-employed or those who answered 'Other' or 'Don't know'. We group these job-search methods into three major types: marketoriented methods, social networks and hierarchical methods, as shown in Table 10.1. 
Table 10.1 Methods Used in Job-Search Processes, AuSSA 2007 (per cent)

\begin{tabular}{|c|c|c|c|}
\hline & $\begin{array}{r}\text { Main method } \\
\text { used in job } \\
\text { search }\end{array}$ & $\begin{array}{r}\text { Most important } \\
\text { method for } \\
\text { getting a job } \\
\text { interview }\end{array}$ & $\begin{array}{r}\text { Most important } \\
\text { method for } \\
\text { getting a job }\end{array}$ \\
\hline Market-oriented methods & $(74.2)$ & $(75.5)$ & (73.7) \\
\hline Looked at media advertisements & 23.3 & 22.8 & 21.9 \\
\hline Used university career services & 1.5 & 1.3 & 1.4 \\
\hline Used an employment agency & 7.0 & 8.4 & 7.0 \\
\hline Used the Internet & 8.5 & 9.8 & 6.6 \\
\hline Approached an employer & 18.3 & 22.5 & 22.2 \\
\hline An employer approached me & 15.6 & 10.7 & 14.6 \\
\hline Social networks & $(21.0)$ & $(21.1)$ & (21.6) \\
\hline $\begin{array}{l}\text { Got help or information from family } \\
\text { or relatives }\end{array}$ & 6.6 & 6.5 & 6.3 \\
\hline Got help or information from friends & 11.1 & 10.8 & 11.2 \\
\hline $\begin{array}{l}\text { Got help or information from } \\
\text { acquaintances }\end{array}$ & 3.3 & 3.8 & 4.1 \\
\hline \multicolumn{4}{|l|}{ Hierarchical methods } \\
\hline \multirow[t]{2}{*}{$\begin{array}{l}\text { Reallocated or transferred by } \\
\text { the organisation I work for }\end{array}$} & 4.8 & 3.4 & 4.7 \\
\hline & $(n=1681)$ & $(n=1669)$ & $(n=1752)$ \\
\hline
\end{tabular}

Source: Australian Survey of Social Attitudes 2007.

Two major results should be noted. First, similar numbers of people use the same methods at each stage of the job search. For example, similar percentages of respondents reported that they used social networks as the main method for job searching (21 per cent), as the most important method for getting a job interview (21.1 per cent) and as the most important method for getting a job (21.6 per cent). Market-oriented methods are the main methods used in job searching by 74.2 per cent of people, the most important method for getting a job interview by 75.5 per cent and the most important method for getting a job by 73.7 per cent. For hierarchical methods, the percentages are respectively 4.8, 3.4 and 4.7. Second, although market-oriented methods predominate in each stage of job searching, social networks also play a non-negligible role and hierarchical methods are noticeable as well. ${ }^{1}$

1 This result can be compared with that of the Job Search Experience Survey, which was conducted by the Australian Bureau of Statistics among employed people in 2007. The Job Search Experience Survey inquired about all steps taken to attain a job by employees who started their current job in the previous 12 months, so people may appear in more than one category of job-search methods. In this case, 27.5 per cent of respondents replied that they 'contacted friends or relatives' in their job searches (ABS 2007). In contrast, the AuSSA 2007 specifically asked which method was used as the main method in job searches; hence, in our coding, people do not fall into more than one category. The percentage of mainly using social networks turned out to be about 21 per cent. In addition, the AuSSA 2007 made a considerable contribution by exploring the utilisation of hierarchical methods in job-search processes. 


\section{Who uses which methods?}

Given the different job-search methods used in Australian labour markets, do different groups of people use different methods? According to international research, the use of job-search methods varies for different people. Take the use of social networks, for example. Several factors may lead to variations in using networks to find jobs (Marsden and Gorman 2001). The first is gender. Some researchers argue that women make less use of social networks for finding jobs than men do because women's networks have more kin relations, more female ties and fewer colleagues than do men's; these kinds of networks are assumed to contain less valuable sources of job information than men's networks, which are potentially more diverse and less based in family and kinship ties (Marsden 1987, 1988). This argument has been supported by some research showing that women were less likely to secure jobs via contacts (Corcoran, Datcher and Duncan 1980; Hanson and Pratt 1991). Other research, however, finds that the gender difference in using contacts for job searches is negligible (Drentea 1998; Marx and Leicht 1992), or that social networks provide even higher returns to women than men (Aguilera 2008). Second, race and ethnicity have been found to affect the use of social networks in job searches (Fernandez and FernandezMateo 2006). In the United States, racial and ethnic minorities are more likely to obtain jobs through social networks than non-minorities (Elliot 2000; Green, Tigges and Diaz 1999). Third, age differences in using social contacts for seeking jobs have been reported, with some studies showing a declining use of social networks with age (Corcoran, Datcher and Duncan 1980; Marsden and Hurlbert 1988) but others indicating very small age differences (Kirnan, Farley and Geisinger 1989). Finally, socioeconomic standing has been linked to using social networks in job searches. Most studies find that the use of social networks is more common among people in lower socioeconomic positions, such as the less-educated (Marx and Leicht 1992), blue-collar employees (Rees and Shultz 1970) and the poor (Green, Tigges and Browne 1995). There are, however, some contradictory findings pointing to the use of social networks by people in professional or managerial positions. Boxman, De Graaf and Flap (1991) found that managers secured their jobs largely through social networks in the Netherlands, but Falcón (1995) revealed that labourers and construction workers used social networks heavily in job searches while professionals or managers used them much less.

Bearing in mind these mixed findings, we examine who uses different job-search methods. Using AuSSA 2007 data, we explore relationships between job-search methods and the demographic and socioeconomic characteristics of Australians. Apart from the above factors, we also examine whether other factors, like union membership and residency in cities of different size, are correlated with the use of different job-search methods. We assume that being a union member is 
likely to be associated with greater use of social networks in job searches given that unions are membership-based organisations that enable individuals to pool their resources (Meagher and Wilson 2007). We also expect that people living in big cities will tend to more commonly use market methods in job searches because they will have greater access to employment services and other market mechanisms for obtaining job information and because more job opportunities are available in big cities resulting in higher rates of job mobility. As shown in Table 10.2, however, there are no significant statistical associations between job-search methods and gender, age, union membership, residency in a big city (more than 100000 people) or birthplace (Australia or overseas), respectively. To put it another way, in Australian labour markets, women and men, the old and the young, union members and non-members, residents in big cities and those in smaller cities or towns, native-born Australians and migrants do not differ in the kinds of job-search methods they use. For most of these social groups in Table 10.2 about 70-75 per cent of people use market methods, about 20-25 per cent use social networks and about 5 per cent use hierarchical methods.

On the other hand, the statistical associations between job-search methods and university degree, income and occupation are strongly significant. First, compared with people without a university degree, university degree holders are more likely to use market-oriented methods (78 per cent versus 72.2 per cent) and hierarchical methods (7 per cent versus 4 per cent) and less likely to use social networks (15.1 per cent versus 23.8 per cent). Second, compared with low-income people, middle and high-income people more commonly use market-oriented methods (75.5 per cent and 76.6 per cent versus 68.8 per cent) and hierarchical methods (3.9 per cent and 6.8 per cent versus 3.5 per cent), but their use of social networks is much lower (19.5 per cent and 17.7 per cent versus 27.7 per cent). Third, among eight major categories of occupations, labourers are least likely to use market-oriented and hierarchical methods (55.3 per cent and 0.7 per cent respectively) but have the highest use of social networks (44 per cent). In contrast, managers and professionals have the highest use of marketoriented methods (both more than 76 per cent) and hierarchical methods (both more than 7 per cent) but the lowest use of social networks (both less than 16 per cent). 
Table 10.2 Associations between Job-Search Methods and Demographic and Socioeconomic Characteristics, AuSSA 2007 (per cent)

\begin{tabular}{|c|c|c|c|}
\hline & \multicolumn{3}{|c|}{ Job-search methods } \\
\hline Gender & Market methods & $\begin{array}{r}\text { Social } \\
\text { networks }\end{array}$ & $\begin{array}{r}\text { Hierarchical } \\
\text { methods }\end{array}$ \\
\hline Male $(n=770)$ & 74.4 & 20.4 & 5.2 \\
\hline \multirow[t]{2}{*}{ Female $(n=975)$} & 73.0 & 22.7 & 4.3 \\
\hline & \multicolumn{3}{|c|}{$\mathrm{x}^{2}=1.9, \mathrm{p}: \mathrm{ns}$} \\
\hline Age & Market methods & $\begin{array}{r}\text { Social } \\
\text { networks }\end{array}$ & $\begin{array}{r}\text { Hierarchical } \\
\text { methods }\end{array}$ \\
\hline 34 and below $(n=375)$ & 76.3 & 20.8 & 2.9 \\
\hline $35-49(n=537)$ & 70.6 & 22.9 & 6.5 \\
\hline $50-64(n=521)$ & 76.2 & 19.8 & 4.0 \\
\hline \multirow[t]{2}{*}{65 and above ( $\mathrm{n}=299)$} & 72.2 & 23.1 & 4.7 \\
\hline & \multicolumn{3}{|c|}{$x^{2}=10.0, p: n s$} \\
\hline University degree & Market methods & $\begin{array}{r}\text { Social } \\
\text { networks }\end{array}$ & $\begin{array}{r}\text { Hierarchical } \\
\text { methods }\end{array}$ \\
\hline Yes $(n=445)$ & 78.0 & 15.1 & 7.0 \\
\hline \multirow[t]{2}{*}{ No $(n=1275)$} & 72.2 & 23.8 & 4.0 \\
\hline & \multicolumn{3}{|c|}{$x^{2}=19.2, p<0.001$} \\
\hline Income & Market methods & $\begin{array}{r}\text { Social } \\
\text { networks }\end{array}$ & $\begin{array}{r}\text { Hierarchical } \\
\text { methods }\end{array}$ \\
\hline Low $(n=452)$ & 68.8 & 27.7 & 3.5 \\
\hline Middle $(\mathrm{n}=610)$ & 76.6 & 19.5 & 3.9 \\
\hline \multirow[t]{2}{*}{ High $(n=514)$} & 75.5 & 17.7 & 6.8 \\
\hline & \multicolumn{3}{|c|}{$x^{2}=21.8, p<0.001$} \\
\hline Occupation & Market methods & $\begin{array}{r}\text { Social } \\
\text { networks }\end{array}$ & $\begin{array}{r}\text { Hierarchical } \\
\text { methods }\end{array}$ \\
\hline Managers $(n=177)$ & 76.8 & 15.3 & 7.9 \\
\hline Professionals ( $n=403$ ) & 78.9 & 14.1 & 7.0 \\
\hline Technicians and trades workers $(n=215)$ & 74.4 & 23.3 & 2.3 \\
\hline Community and personal service workers ( $n=180$ ) & 70.5 & 23.9 & 5.6 \\
\hline Clerical and administrative workers ( $n=343$ ) & 73.8 & 21.6 & 4.6 \\
\hline Sales workers $(n=146)$ & 76.7 & 20.6 & 2.7 \\
\hline Machinery operators and drivers ( $\mathrm{n}=89$ ) & 70.8 & 27.0 & 2.2 \\
\hline \multirow[t]{2}{*}{ Labourers $(n=141)$} & 55.3 & 44.0 & 0.7 \\
\hline & \multicolumn{3}{|c|}{$x^{2}=75.0, p<0.001$} \\
\hline Union member & Market methods & $\begin{array}{r}\text { Social } \\
\text { networks }\end{array}$ & $\begin{array}{r}\text { Hierarchical } \\
\text { methods }\end{array}$ \\
\hline Yes $(n=1007)$ & 72.8 & 21.5 & 5.7 \\
\hline \multirow[t]{2}{*}{ No $(n=723)$} & 75.0 & 21.6 & 3.5 \\
\hline & \multicolumn{3}{|c|}{$x^{2}=4.6, p: n s$} \\
\hline
\end{tabular}




\begin{tabular}{lrrr}
\hline & \multicolumn{3}{c}{ Job-search methods } \\
\hline Resident in big cities & Market methods & $\begin{array}{r}\text { Social } \\
\text { networks }\end{array}$ & $\begin{array}{r}\text { Hierarchical } \\
\text { methods }\end{array}$ \\
Yes $(\mathrm{n}=1062)$ & 73.8 & 21.7 & 4.5 \\
No $(\mathrm{n}=664)$ & 73.9 & 21.1 & 5.0 \\
& $\mathrm{x}^{2}=$ & $0.2, \mathrm{p}: \mathrm{ns}$ \\
Birthplace & Market methods & Social & Hierarchical \\
networks & methods \\
Australia $(\mathrm{n}=1375)$ & 73.5 & 21.7 & 4.9 \\
Overseas $(n=375)$ & 74.4 & 21.6 & 4.0 \\
& \multicolumn{3}{c}{$\mathrm{x}^{2}=0.5, \mathrm{p}: \mathrm{ns}$} \\
\hline
\end{tabular}

Source: Australian Survey of Social Attitudes 2007.

A pattern of using job-search methods by different people thus emerges. People who have a university degree, higher income or a professional and managerial occupation are more likely to use market-oriented methods and hierarchical methods in their job searches than people without a university degree, with low income or in labouring occupations. The last groups rely relatively strongly on social networks. These findings coincide with most extant studies revealing the use of social networks is more common among people in lower socioeconomic positions (Falcón 1995; Green, Tigges and Browne 1995; Marx and Leicht 1992; Rees and Shultz 1970). They also accord with information from the Australian Bureau of Statistics (ABS) on job-search experiences. About 46 per cent of unemployed persons contacted friends or relatives to find a job whereas only about 27 per cent of employed persons who started their current job in the previous 12 months did so (ABS 2007). As noted by Marsden and Gorman (2001), what these findings mean is not always explicit. To clarify these findings, we need to examine the institutional conditions of the Australian labour market.

Australia has one of the most open employment service markets in the world (Dockery 1999). Market mechanisms are highly developed or encouraged. Generally, information about job openings or employment opportunities is open to the public and allows equal access via different channels. A range of employment services or agencies, private and public, is available to provide advice and training to help people find and keep a job or make a career change. With the development of the Internet, online recruitment and applications are widely adopted, which are convenient for both employers and job-seekers. Employment processes are transparent and subject to policy and legislation that prohibit discrimination and emphasise formal and explicit hiring processes. Under such circumstances, people with higher levels of human capital such as a university degree are likely to have better access to information in labour markets and can also straightforwardly choose market-oriented methods for job searches because these formal market processes correspond with the formal 
processes of employment selection that characterise much of the Australian labour market. This is unlike the situation in some transitional economies such as China and Russia, where, due to underdevelopment of labour markets and institutional gaps embedded in employment processes, job information can be a scarce resource provided as a favour by influential helpers in job-seekers' mobilised social networks (Bian 1997; Yakubovich and Kozina 2000).

Our analysis of the AuSSA 2007 data also reveals that university degree holders have significantly higher incomes and are more likely to occupy professional or managerial positions than those without degrees ${ }^{2}$. Again, these jobs are subject to formal employment processes, educational qualifications, skills and experience are often requirements and market methods are therefore one way to match job-seekers appropriately to these jobs. In addition, since internal transfers commonly entail promotions, these kinds of hierarchy methods tend to be more frequently used by job-seekers who have relatively high income or a professional or managerial position within organisations. In contrast, labourers' jobs are more likely to be short-term or casual, lacking continuity and security; they have less in the way of formal requirements; and their unstable employment and peripheral status may inhibit investment in training from employers, causing the problem of limited opportunities for advancement in internal labour markets (Atkinson and Meager 1986). Without internal labour markets (that is, career ladders within an organisation), there are few opportunities for transfer or promotion. Labourers have opportunities to use market methods, but unlike those in more privileged occupations, informal social networks are also viable because there are almost no formal requirements for labouring jobs. Labourers may therefore choose to use social networks that are more flexible, convenient and relatively inexpensive to find jobs (Corcoran, Datcher and Duncan 1980). For instance, job information can be acquired from networks in the course of conversations about other things, which does not require either buying services or spending considerable time looking.

\section{Network resources and social ties in job searches}

Using social networks has been found to be a common job-search strategy in many countries (Franzen and Hangartner 2006). Australia is not an exception. In this section, we further investigate what social resources job-seekers use in their social networks and what types of social ties mainly help out.

\footnotetext{
2 Within our working sample, we calculated the association between a university degree and occupying a professional or managerial position as well as the association between a university degree and income levels. It turns out that both associations are statistically significant $(\mathrm{p}<0.001)$. In detail, among 445 university degree holders, 76.2 per cent have a professional or managerial position. Again, among 430 university degree holders, 85 per cent belong to middle or high-level income groups.
} 
The labour market is a competitive arena. Job-seekers bring various resources or forms of capital to compete for a vacancy and its expected returns. Three kinds of capital are especially relevant: financial capital (economic resources), human capital (skills, experience and education) and social capital (networks). Financial capital and human capital are individual resources while social capital is a relational resource, which arises from people's involvement in relationships with others. Human-capital theory (Becker 1993; Schultz 1960) in economics ascribes market returns (earnings) to individual productivity. By investing in education and technical skill training, people make themselves more productive and thus increase the economic returns they are able to earn. According to some sociologists, however, human capital is ineffective without social capital, which provides opportunities to apply human capital effectively. In an imperfect market, social capital (networks) helps people take best advantage of their human capital (Burt 1992, 1997) by finding appropriate jobs. The conceptualisation and measurement of social capital vary greatly in social research; we adopt the concept and measurement of social resources theory (Lin 2001). This argues that social capital is a feature of constraints and opportunities associated with social relationships between actors (individuals, organisations, and so on) and is a resource embedded in networks. Social capital is best understood by examining the mechanisms and processes by which embedded resources in social networks are used by actors to achieve certain objectives. As an example, searching for a job can be understood as a process by which the job-seeker employs social resources (resources based in social networks) in addition to his/her human capital and financial capital to realise the instrumental goal of getting a job.

Social networks provide different kinds of resources that are useful for job searching. Information and influence are widely recognised as two major kinds of resources (Bian 1997; Flap and Boxman 2001; Granovetter 1973, 1974). Generally speaking, economists who examine network resources emphasise the role played by information in addressing 'information asymmetry' or 'information gaps' in real labour markets (Akerlof 1970; Rees 1966). Information gaps occur when employers and/or potential employees do not have access to some of the information needed to make optimal decisions in relation to jobs and employment. Likewise, sociologists whose work is based on Western societies also typically emphasise the role of information. Granovetter's (1973) tremendously influential work, for instance, highlighted how people's weak ties (that is, ties outside their close personal relationships) allowed them access to new information that was very important for job searches. In contrast, scholars present a different view in Eastern countries like China, Singapore and Hong Kong and transitional state socialist countries like China and Russia (Bian 1997; Bian and Soon 1997; Clarke 1999; Yakubovich and Kozina 2000). These researchers claim that strong ties with norms of trust and obligation are more advantageous in accessing influence and favour for job attainment. Bian 
(1997) put forward the hypothesis of the strength of strong ties, distinguishing between weak ties used to gather job information in a market economy and strong ties used to access influence from authority in a state socialist economy where labour markets are either greatly altered or nonexistent.

What kinds of social resources do Australian job-seekers get when they use social networks to help them find a job? The AuSSA 2007 asked respondents about the main help obtained from their social contacts (acquaintances, family members, relatives and friends) when searching for their current or last job. In addition to information and influence, we also examined whether job-seekers sought emotional support from their social contacts. We summarise the access to social resources by job searchers who had help from social networks in Table 10.3. Information is the major resource accessed by these job searchers; social contacts either 'provided employment information' (28.7 per cent) or 'helped to prepare a job application' (16.5 per cent). Emotional support is the second most common type of resource (34.6 per cent) while influence is least commonly provided by social contacts who 'approached people to exert influence' (10.5 per cent) or 'solved practical problems' (2.4 per cent).

\section{Table 10.3 Network Resources Accessed by Job Searchers, AuSSA 2007 (per cent)}

\begin{tabular}{lr}
\hline Network resources & \\
\hline Information & 28.7 \\
They provided employment information & 16.5 \\
$\quad$ They helped to prepare a job application & 10.5 \\
Influence & 2.4 \\
$\quad$ They approached people to exert influence on my behalf \\
$\quad$ They helped to solve practical problems & 34.6 \\
Emotional support & 7.3 \\
$\quad$ They provided emotional support & (n = 1219) \\
Other help
\end{tabular}

Source: Australian Survey of Social Attitudes 2007.

As reviewed, the strength of ties is another aspect of significance in social network studies of job searches (Bian 1997; Granovetter 1973). Some researchers argue that strong ties (close personal contacts) are more effective in helping people find jobs, while other researchers argue that weak ties (contacts who are outside an individual's close personal relationships) are more effective. We measure the strength of social ties by using a question provided in the AuSSA 2007: 'Was there one particular person among those who helped you to get this job?' If a respondent answered that 'a friend, a family member or relative' helped out, we categorise this case as one that 
utilised strong ties. If a respondent chose to reply 'an acquaintance or other people', we categorise this case as one that used weak ties. As shown in Table 10.4, among 908 respondents who used social networks in job-search processes, more than 77 per cent used strong ties while about 23 per cent used weak ties.

Table 10.4 Types of Social Ties Mobilised by Job Searchers, AuSSA 2007 (per cent)

\begin{tabular}{lr}
\hline Types of social ties & \\
\hline Strong ties & \\
$\quad$ Friends & 38.1 \\
$\quad$ Family members/relatives & 39.2 \\
Weak ties & \\
$\quad$ Acquaintances & 15.2 \\
Other people & 7.5 \\
& $(\mathrm{n}=908)$ \\
\hline
\end{tabular}

Source: Australian Survey of Social Attitudes 2007.

The debate about whether strong or weak ties matter more in the job-search process (Bian 1997; Granovetter 1973) hinges on the kinds of social resources social contacts provide to job-seekers. Advocates of the 'weak tie hypothesis' argue that weak ties lie outside people's immediate social networks and therefore crosscut social circles to provide new information that people would not otherwise have. This new information helps to secure a job and achieve better employment outcomes. Proponents of the 'strong tie hypothesis' argue that close personal contacts are more useful for exercising influence. Are strong and weak ties connected to these resources in the Australian labour market as these ideas suggest? In Table 10.5, we continue to examine the association between social ties and network resources, which turns out to be slightly significant $(p<0.1)$; however, the finding differs somewhat from the above assumption in that strong ties were mainly used to access information (56.5 per cent) rather than influence (16.4 per cent) and weak ties helped to access influence to a considerable extent (21.3 per cent).

Table 10.5 Association between Network Resources and Social Ties, AuSSA 2007 (per cent)

\begin{tabular}{lccr}
\hline & \multicolumn{3}{c}{ Network resources } \\
\hline Social ties & Information & Influence & Other help \\
Weak ties $(\mathrm{n}=169)$ & 46.2 & 21.3 & 32.5 \\
Strong ties $(\mathrm{n}=646)$ & 56.5 & 16.4 & 27.1 \\
& \multicolumn{1}{c}{$\mathrm{x}^{2}=5.9, \mathrm{p}<0.1$} \\
\hline
\end{tabular}




\section{Job-search methods and job match}

Real labour markets are not perfect but full of uncertainty (Rees 1966). In economic theory, in perfectly competitive labour markets employers and employees would have complete and accurate information about all relevant characteristics of jobs, employers and job-seekers and this would allow optimal matches between jobs and individuals. Information asymmetries and gaps occur when employers and/or job-seekers lack relevant information. Job-seekers and employers try to minimise information gaps by finding out relevant information, but acquiring information requires spending time, effort and money (Stigler 1961); it is costly. Social ties are one relatively inexpensive way to obtain rich and trustworthy information (Marsden and Gorman 2001). Granovetter (1974, 1981) found that job-seekers and employers preferred information derived from weakly tied personal contacts. This kind of information is seen as less costly and of better quality than that obtained through other means. Other research has also shown that personal contacts and referral networks can promote better matches between individuals and positions because people hired through these network methods not only better understand their jobs and working environment at the start of employment but also are motivated to receive informal training from other employees (Fernandez, Castilla and Moore 2000; Manwaring 1984). Thus, for both sociologists (Fernandez and Castilla 2001; Granovetter 1981) and economists (Javanovic 1979; MacDonald 1980), job matching between individuals and positions has become an essential aspect of arguments about the effects of social networks on job-search and employment outcomes. Very little empirical research has, however, investigated job matching - that is, the fit between job-seekers and the requirements of skills or working experience for a job position. The AuSSA 2007 addresses this gap, making it possible to compare the quality of job matches arising from social networks with the quality of matches obtained through other means.

We look first at an overview of job matching in Australian labour markets. In the AuSSA 2007, respondents were asked how well their qualifications, skills and experience matched the jobs they obtained. About 13 per cent of job-seekers were overqualified for their positions, 72.4 per cent had a good match, 3.4 per cent were underqualified and 11.4 per cent said that there was no requirement in skills or experience for their positions (Figure 10.1). Overall, a majority of Australian jobs were matched well with qualified job applicants. 


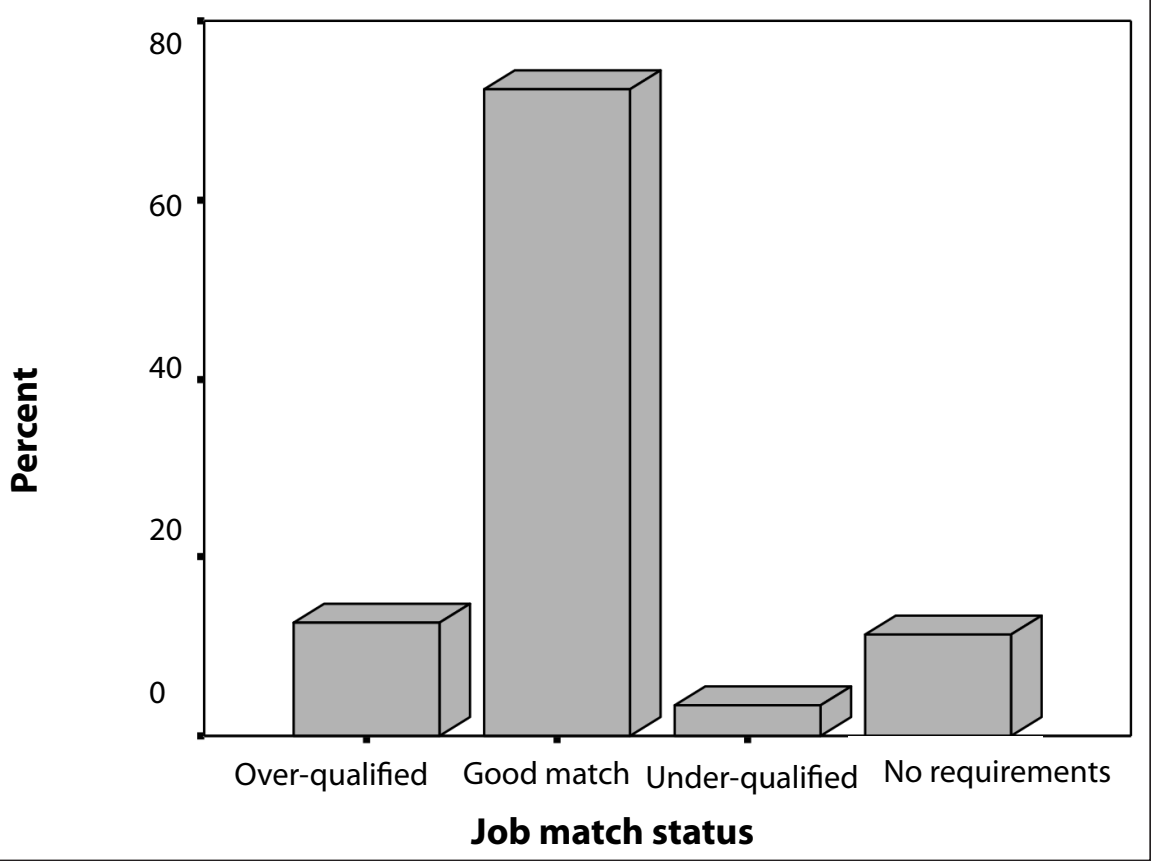

Figure 10.1 Job Matching between Job-Seekers and Positions, AuSSA $2007(n=1958)$

Source: Australian Survey of Social Attitudes 2007.

We next examine whether different job-search methods produce different quality job matches (Table 10.6). It appears they do. Some 73.6 per cent of jobseekers who used market-oriented methods ended up in a good match between their qualifications and job positions, and 26.4 per cent were not matched well; however, only 67 per cent of job-seekers who used social networks realised a good match, with the rest (one-third) not matched well. Hierarchical methods were associated with the highest percentage of good matches, with 81.7 per cent; only 18.3 per cent of the users of hierarchical methods were not matched well.

These results suggest that in Australian labour markets, market methods and hierarchical methods outperform social networks in assisting a good match between applicants and job positions. To provide convincing support for this assertion, we look at the effect of using these job-search methods on job matches with other demographic and socioeconomic characteristics of job-seekers being held constant in a statistical model. A binary logistic regression is employed for this purpose (Table 10.7). ${ }^{3}$

3 In this model, market-oriented methods, social networks and hierarchical methods are three dummy variables that are measured by using the question 'On the whole, which one method was most important for getting your current/last job?' in the AuSSA 2007 (see details in the section on 'Job-search methods'). Control variables include gender, age, years of schooling, university degree, professional or managerial position, income, union membership, birthplace and residency in a big city. 
Table 10.6 Association between Job-Matching Status and Job-Search Methods, AuSSA 2007 (per cent)

\begin{tabular}{ccr}
\hline & \multicolumn{2}{c}{ Job-matching status } \\
\hline Job-search methods & Good match & Not matched well \\
Market methods $(\mathrm{n}=1282)$ & 73.6 & 26.4 \\
Social networks $(\mathrm{n}=379)$ & 67.0 & 33.0 \\
Hierarchical methods $(\mathrm{n}=82)$ & 81.7 & 18.3 \\
& $\mathrm{x}^{2}=10.0, \mathrm{p}<0.01$ & \\
\hline
\end{tabular}

Source: Australian Survey of Social Attitudes 2007.

Table 10.7 Binary Logistic Regression in Predicting Effects of Job-Search Methods on Job Match, AuSSA 2007

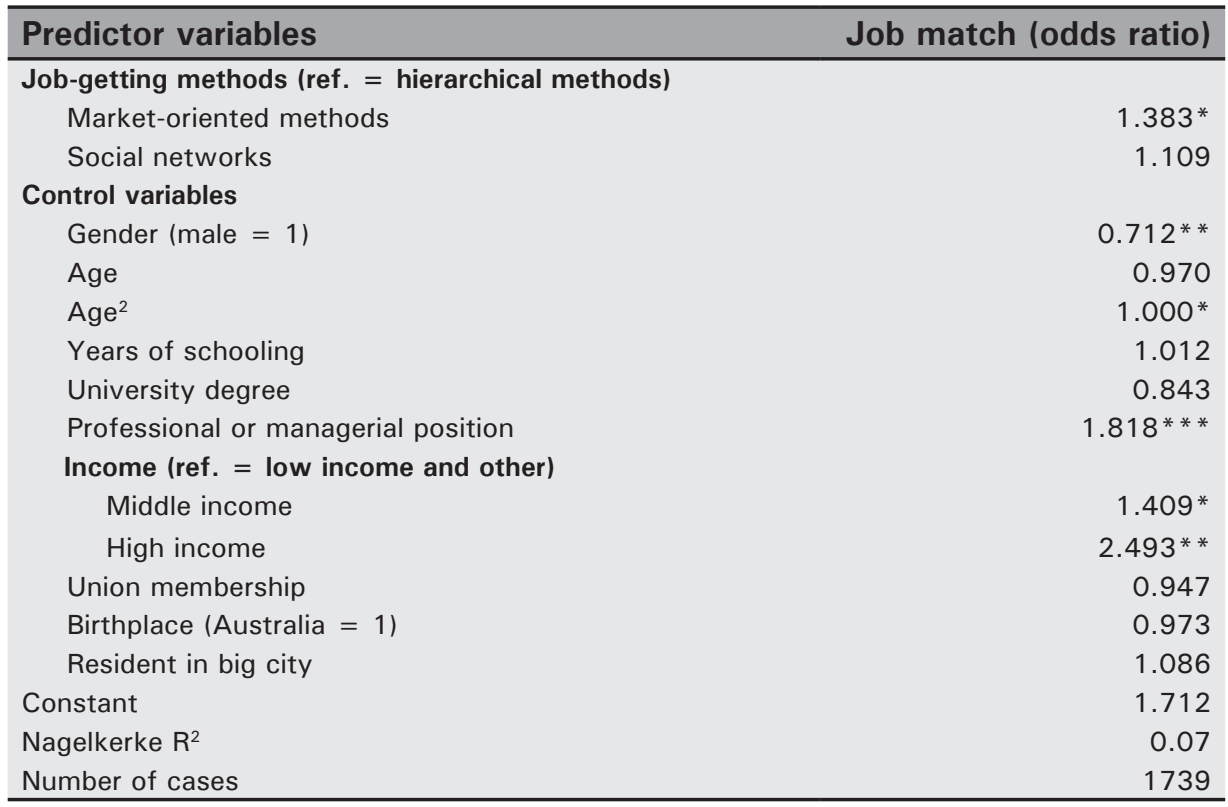

${ }^{*} \mathrm{p}<0.05$

${ }^{* *} \mathrm{p}<0.01$

${ }^{* * *} \mathrm{p}<0.001$

Source: Australian Survey of Social Attitudes 2007.

This analysis shows that, compared with hierarchical methods, market-oriented methods have a higher probability of leading to a good job match but social networks do not. After controlling the demographic and socioeconomic characteristics of job-seekers, social networks do not have any statistically significant advantages over hierarchical methods or market-oriented methods in matching job applicants to positions. These findings differ from the positive 
effect of social networks on job matching found in previous studies (Fernandez, Castilla and Moore 2000; Manwaring 1984). How might we interpret them? First, information flows in Australian labour markets are highly marketised, as we have already seen. Thus, the information acquired through market channels can meet the needs of making a good match between applicants and job positions, leaving little room or necessity for social networks. Second, hierarchical methods may have positive effects on job matches because the internal transfer or reallocation within organisations is often based on employers' knowledge of the people and the positions with which they will be matched. Third, as shown above, Australian job-seekers heavily mobilised their strong ties instead of weak ties to find a job. If Granovetter $(1973,1974)$ is correct that strong ties do not provide high-quality job information, social networks may not lead to good job matches.

\section{Conclusion}

In this chapter, we have examined the question of how Australians search for jobs using AuSSA 2007 data. This is one of the first Australian analyses of this type. Our major findings are briefly summarised and discussed below.

\section{Job-search methods coexist in Australian labour markets}

We differentiate job-search methods into market-oriented methods, social networks and hierarchical methods (Bian 2002; Granovetter 1995). All these methods are used by Australians to search for jobs, to get job interviews and, finally, to locate a job. As in most Western countries, in Australia, market-oriented methods predominate. Social networks play a significant role in helping people look for jobs, and hierarchical methods are used to realise internal transfers or reallocation within work organisations.

\section{The use of job-search methods varies by people's socioeconomic standing}

Internationally, research has shown that the use of job-search methods is affected by the characteristics of job-seekers, such as gender, race, age, socioeconomic standing, and so on. We do not find differences between men and women, the old and the young, union members and non-members, residents in big cities and those in smaller cities or towns, the Australian born and migrants in terms of their use of job-search methods. Rather, socioeconomic standing is the main factor causing variations in using job-search methods. People who have a university degree, higher income or a professional and managerial occupation are more likely to use market-oriented and hierarchical methods 
in their job searches. People who do not have a university degree, have a low income or do a labouring job are more dependent on using social networks than other job-search methods. This finding is consistent with research from other Western countries (Falcón 1995; Green, Tigges and Browne 1995; Marx and Leicht 1992; Rees and Shultz 1970). There are at least two possible reasons why this occurs. First, successful applicants for high-status jobs may prefer formal market methods over informal methods that rely on social networks. Second, high-status jobs are more likely to have formal entry requirements associated with them than are low-status jobs. For high-status jobs, market methods will likely provide better information to employers and job-seekers about these requirements and the relevant characteristics of job-seekers than will social networks. Market methods will therefore produce better matches than social networks. Individuals who are poorly matched are more likely to be screened out during the selection process for high-status jobs than for low-status jobs because it is more likely to be apparent that they do not meet the formal criteria. In Australia the connections between market methods and high-status jobs probably reflect both these processes.

\section{Strong ties are the main provider of information for job-seekers}

Information and influence are widely recognised as two major kinds of resources flowing through social networks in job-search processes. As implied in the literature, the strength of weak ties (that is, acquaintances) lies in acquiring extensive and non-redundant information for locating a better job (Granovetter 1973), and the strength of strong ties (that is, friends, family members or relatives) lies in accessing influence from helpers who are either decisive in hiring or can provide favours to solve practical problems in job searches (Bian 1997). According to our data analysis, strong ties were mainly used to provide information for people who had contacted social ties in their job-search processes. Due to the 'homophilous' or 'like me' characteristics of social interactions associated with strong ties, people in low socioeconomic positions who heavily rely on strong ties may encounter difficulties in getting access to high-quality information when seeking jobs. This problem of reliance on 'unproductive networks' (Fernandez and Fernandez-Mateo 2006) deserves serious attention because it suggests that people who are socioeconomically disadvantaged may rely more heavily on poorer quality job-search methods, potentially compounding their disadvantage. 


\section{Social networks do not have relatively significant effects on realising good job matches}

Job matching between individuals and positions is an essential element in the process of getting a job. Job-search methods contribute to the match. In Australia people who use market-oriented methods in their job searches are more likely to achieve good matches between their qualifications and employers' requirements compared with those who use hierarchical methods. In contrast, social networks do not have a significant effect on helping people to be well matched to job positions compared with hierarchical methods. This finding may reflect the high proportion of strong ties people use when drawing on social networks for job information. On the other hand, information flows via market channels or hierarchical methods appear to work well in the Australian labour market. Information flows are essential for making good job matches.

Two immediate implications follow from these results. First, relying on social networks is unproductive because these methods do not significantly increase the likelihood of getting a good job match. Second, if social networks are associated with comparatively poorer job matches than market and hierarchical methods, using social networks to get jobs could increase the employment insecurity associated with these jobs. Since social networks are more likely to be used by people without university degrees, with low incomes and in labouring jobs, the use of social networks could contribute further to the insecurity of people who are already vulnerable in the labour market. It is also possible that our results understate the extent to which social networks produce poor-quality matches, because some poor-quality matches will also be screened out during the employment process, although perhaps not as many as for higher-status jobs, as we have already noted.

One other implication derived from our research is also noteworthy. The study of job searches should be located in its institutional context. The institutional context is given by the formal and informal rules within which job searching takes place, including the laws, regulations, policies, ideas and taken-for-granted assumptions about how one 'normally' gets a job. Job searching is not a purely economic activity that occurs within a disembodied market but is 'embedded' in social networks that are themselves located in broader institutional contexts (Granovetter 1995). We have concentrated on looking at the role of social networks, but there are many ways to extend this area of research through a more developed institutional perspective that recognises factors such as the industrial relations system, employment policies and practices, and variations across occupations, industries and organisations. It is important to take seriously this context in the analysis of job-search processes. 


\section{References}

Aguilera, Michael. 2008. 'Personal networks and the incomes of men and women in the United States: do personal networks provide higher returns for men or women?'. Research in Social Stratification and Mobility 26(3): 221-33.

Akerlof, George. 1970. 'The market for "lemons": quality uncertainty and the market mechanism'. The Quarterly Journal of Economics 84(3): 488-500.

Atkinson, John and Meager, Nigel. 1986. 'Is flexibility just a flash in the pan?'. PersonnelManagement (September): 26-9.

Australian Bureau of Statistics (ABS). 2007. Job Search Experience, Catalogue no. 6222.0. Canberra: Australian Bureau of Statistics.

Becker, Gary. 1993. Human Capital: A theoretical and empirical analysis, with special reference to education. Chicago and London: University of Chicago Press.

Bian, Yanjie. 1997. 'Bringing strong ties back in: indirect ties, network bridges, and job searches in China'. American Sociological Review 62(3): 266-85.

Bian, Yanjie. 2002. 'Institutional holes and job mobility process: guanxi mechanisms in China's emerging labor markets'. In Social Connections in China: Institutions, culture, and the changing nature of guanxi, eds Thomas Gold, Doug Guthrie and David Wank, pp. 117-36. Cambridge: Cambridge University Press.

Bian, Yanjie. 2004. 'The networking space in occupational mobility: a comparison of Hong Kong and inland cities of China'. Hong Kong Journal of Sociology 5: 103-17.

Bian, Yanjie and Soon, Ang. 1997. 'Guanxi networks and job mobility in China and Singapore'. Social Forces 75(3): 981-1006.

Boxman, Ed A., De Graaf, Paul M. and Flap, Hendrik D. 1991. 'The impact of social and human capital on the income attainment of Dutch managers'. Social Networks 13(1): 51-73.

Bridges, William and Villemez, Wayne J. 1986. 'Informal hiring and income in the labor market'. American Sociological Review 51(3): 574-82.

Burt, Ronald S. 1992. Structural Holes: The social structure of competition. Cambridge, Mass.: Harvard University Press.

Burt, Ronald S. 1997. 'The contingent value of social capital'. Administrative Science Quarterly 42(1): 339-65. 
Clarke, Simon. 1999. The Formation of a Labour Market in Russia. Cheltenham, UK: Edward Elgar.

Corcoran, Mary, Datcher, Linda and Duncan, Greg. 1980. 'Information and influence networks in labor markets'. In Five Thousand American Families' Patterns of Economic Progress. Volume 8, eds Greg J. Duncan and James N. Morgan, pp. 1-37. Ann Arbor, Mich.: Institute for Social Research.

De Graaf, Nan D. and Flap, Hendrik D. 1988. 'With a little help from my friends: social resources as an explanation of occupational status and income in West Germany, the Netherlands, and the United States'. Social Forces 67(1): 452-72.

Dockery, A. Michael. 1999. 'Evaluating the job network'. Australian Journal of Labour Economics 3(2): 131-58.

Drentea, Patricia. 1998. 'Consequences of women's formal and informal job search methods for employment in female-dominated jobs'. Gender and Society 12(3): 321-38.

Elliot, James R. 2000. 'Class, race, and job matching in contemporary urban labor markets'. Social Science Quarterly 81(4): 1036-51.

Falcón, Luis M. 1995. 'Social networks and employment for Latinos, blacks, and whites'. New England Journal of Public Policy 11: 17-28.

Fernandez, Roberto M. and Castilla, Emilio J. 2001. 'How much is that network worth? Social capital in employee referral networks'. In Social Capital: Theory and research, eds Nan Lin, Ronald S. Burt and Karen Cook, pp. 85-104. New York: Aldine de Gruyter.

Fernandez, Roberto M., Castilla, Emilio J. and Moore, Paul. 2000. 'Social capital at work: networks and employment at a phone center'. American Journal of Sociology 105(5): 1288-356.

Fernandez, Roberto M. and Fernandez-Mateo, Isabel. 2006. 'Networks, race, and hiring'. American Sociological Review 71(1): 42-71.

Flap, Henk and Boxman, Ed. 2001. 'Getting started: the influence of social capital on the start of the occupational career'. In Social Capital: Theory and research, eds Nan Lin, Ronald S. Burt and Karen Cook, pp. 159-81. New York: Aldine de Gruyter.

Franzen, Axel and Hangartner, Dominik. 2006. 'Social networks and labour market outcomes: the non-monetary benefits of social capital'. European Sociological Review 22(4): 353-68. 
Australia: Identity, Fear and Governance in the 21 st Century

Granovetter, Mark. 1973. 'The strength of weak ties'. American Journal of Sociology 78(6): 1360-80.

Granovetter, Mark. 1974. Getting a Job: A study of contacts and careers. Cambridge, Mass.: Harvard University Press.

Granovetter, Mark. 1981. 'Toward a sociological theory of income differences'. In Sociological Perspectives on Labour Markets, ed. Ivar Berg, pp. 11-47. New York: Academic Press.

Granovetter, Mark. 1995. 'Afterword 1994: reconsiderations and a new agenda'. In Getting a Job: A study of contacts and careers, pp. 139-82. Chicago: University of Chicago Press.

Green, Gary P., Tigges, Leann M. and Browne, Irene. 1995. 'Social resources, job search, and poverty in Atlanta'. Research in Community Sociology 5: 161-82.

Green, Gary P., Tigges, Leann M. and Diaz, Daniel. 1999. 'Racial and ethnic differences in job-search strategies in Atlanta, Boston, and Los Angeles'. Social Science Quarterly 80(2): 263-78.

Hanson, Susan and Pratt, Geraldine. 1991. 'Job search and the occupational segregation of women'. Annals of the Association of American Geographers 81(2): 229-53.

Javanovic, Boyan. 1979. 'Job matching and the theory of turnover'. The Journal of Political Economy 87(5): 972-90.

Kirnan, Jean Powell, Farley, John A. and Geisinger, Kurt F. 1989. 'The relationship between recruiting source, applicant quality, and hire performance: an analysis by sex, ethnicity, and age'. Personnel Psychology 42(2): 293-308.

Lin, Nan. 2001. Social Capital: A theory of social structure and action. Cambridge: Cambridge University Press.

Lin, Nan, Ensel, Walter and Vaughn, John. 1981. 'Social resources and strength of ties: structural factors in occupational status attainment'. American Sociological Review 46(4): 393-405.

MacDonald, Glenn M. 1980. 'Person-specific information in the labor market'. The Journal of Political Economy 88(3): 578-97.

Manwaring, Tony. 1984. 'The extended internal labour market'. Cambridge Journal of Economics 8(2): 161-87.

Marsden, Peter V. 1987. 'Core discussion networks of Americans'. American Sociological Review 52(1): 122-31. 
Marsden, Peter V. 1988. 'Homogeneity in confiding networks'. Social Networks 10(1): 57-76.

Marsden, Peter V. and Gorman, Elizabeth H. 2001. 'Social networks, job changes, and recruitment'. In Sourcebook of Labor Markets: Evolving structures and processes, eds Ivar Berg and Arne L. Kalleberg, pp. 467-502. New York: Kluwer Academic/Plenum Publishers.

Marsden, Peter V. and Hurlbert, Jeanne S. 1988. 'Social resources and mobility outcomes: a replication and extension'. Social Forces 66(4): 1038-59.

Marx, Jonathan and Leicht, Kevin T. 1992. 'Formality of recruitment to 229 jobs: variations by race, sex and job characteristics'. Sociology and Social Research 76: 190-6.

Meagher, Gabrielle and Wilson, Shaun. 2007. 'Are unions regaining popular legitimacy in Australia?'. In Australian Social Attitudes 2, eds David Denemark, Gabrielle Meagher, Shaun Wilson, Mark Western and Timothy Phillips, pp. 195-216. Sydney: UNSW Press.

Phillips, T., Mitchell, D., Tranter, B., Clark, J. and Reed, K. 2008. The Australian Survey of Social Attitudes, 2007. Canberra: Australian Social Science Data Archive, The Australian National University.

Rees, Albert. 1966. 'Information networks in labor markets'. American Economic Review 56(2): 559-66.

Rees, Albert and Shultz, George. 1970. Workers and Wages in an Urban Labor Market. Chicago: University of Chicago Press.

Schultz, Theodore W. 1960. 'Investment in human capital'. American Economic Review 51(1): 1-17.

Stigler, George J. 1961. 'The economics of information'. The Journal of Political Economy 60(3): 213-25.

Yakubovich, Valery and Kozina, Irina. 2000. 'The changing significance of ties: an explanation of the hiring channels in the Russian transitional labor market'. International Sociology 15(3): 479-500. 